Indonesian Journal of EFL and Linguistics

Vol. 6 No. 1, 2021

eISSN: 2503-4197, pISSN: 2527-5070

www. indonesian-efl-journal.org

doi: http://dx.doi.org/10.21462/ijefl.v6i1.342

\title{
Teachers' Perception toward the Challenges in Online English Teaching during Covid-19 Pandemic
}

\author{
Hermansyah \\ Magister Student of English Education College \\ Mulawarman University Samarinda \\ e-mail: hmsy18@yahoo.com \\ Aridah \\ Lecturer of English Education College \\ Mulawarman University Samarinda \\ e-mail: aridah27@yahoo.com
}

\begin{abstract}
:
Due to the COVID-19 pandemic and government policy to carry out online learning or study from home in Balikpapan, Indonesia, this study aims to describe the teachers' perception of the challenges in the implementation of online learning in teaching English subjects in the learning process and the recommendation to overcome the problems. This research is a qualitative descriptive study. Three English teachers volunteered to participate in this research through invitation at SMK Nusantara Balikpapan. The research data collected through in-depth interviews, which were analyzed descriptively by using interactive techniques. The Thematic analysis is done by collecting data, reducing data, presenting data, and drawing conclusions. The results of the data analysis show that three English teachers were not too familiar with online learning at first, so they still have many obstacles in the teaching process by using online applications or platforms. There are several obstacles, such as using applications or platforms as media, teachers' knowledge, time schedule, teacher and students' motivation, and plagiarism. To run online learning, these obstacles should be overcome.
\end{abstract}

Keywords: covid-19 pandemic, English teaching, online learning challenges, teachers' perception

Indonesian Journal of EFL and Linguistics, 6(1), 2021 


\section{Hermansyah and Aridah}

\section{INTRODUCTION}

Since the 2019 Coronavirus became pandemic and entered Indonesia with the first positive case was founded on March 2, 2020, several policies or steps related to handling and preventing this deadly outbreak have been implemented by the Government of Indonesia. Starting from the application of Social Distancing, Physical Distancing, Selective Limitation, to the implementation of the Large-Scale Social Restriction (PSBB) policy, was carried out. The goal is that the chain of the spread of COVID-19 can be immediately broken. Especially in the World of Education in Indonesia, the Minister of Education and Culture (Kemdikbud, 2020) has asked all schools to provide Ease of Learning in the Covid-19 Emergency. Helping the government and the community, students should study from home, work from home, and carry out social restrictions to break the chain of spreading Coronavirus Disease (Covid-19). The Directorate General of Primary and Secondary Education also appealed to all schools under the auspices of the Minister of Education and Culture with their autonomy to provide flexibility in implementing distance learning during the Covid-19 emergency. One of them is by implementing the Home Learning system or studying at home. Various methods can be chosen, such as assignments, essays, literature reviews, data analysis, independent projects, etc. Different learning media might be utilized, such as e-learning, google, zoom, and other applications.

The Minister of Education provided several references for the implementation of learning from home during this pandemic. There is no specific limitation on what learning materials teachers must provide at home. It is because the access or learning facilities that each student has at home are not the same. To support the learning process from home, the Minister of Education and Culture has collaborated with several telecommunications providers to provide educational quotas to access learning applications or websites. The method of delivering instructional does not impact the curriculum and teaching content, but the selection of strategies for provision and action are taken. Therefore it is necessary to redesign the pedagogy used by educators (Code et al., 2020). According to Irfan et al. (2020), the application of online learning is not accompanied by the ability to use a platform that can support online learning in education policies. So, Nadiem Makarim published an emergency curriculum during the Corona Pandemic. This emergency curriculum is a simplification of the national curriculum. The emergency curriculum was published through the Decree of the Minister of Education and Culture of the Republic of Indonesia Number 719 / P / 2020 concerning Protocols for Implementing Curriculum in Educational Units in Special Conditions. The ministerial decree was signed by Nadiem on August 4, 2020.

Online learning supports study from home when the school closed. Information and Communication Technology (ICT) in education, especially Online learning is the only option during pandemic Covid-19. The use of ICT in education is becoming 
more frequent (Navarro et al., 2020). Aliyyah et al. (2020) stated that Online learning focuses on Internet-based courses by offering synchronous and asynchronous methods. Synchronous is a form of learning with direct interaction between teachers and students who simultaneously uses online forms such as conversations in online chat and video conferences. Asynchronous is learning indirectly using an independent learning approach at different times.

English has still become a foreign language in Indonesia. It has been officially taught in school for a long time. As a foreign language, English has a special status among other foreign languages in Indonesia (Lauder, 2008). This subject is compulsory to teach in junior and senior high school and become one of the national examination subjects. In covid-19 pandemic, the learning language, especially English, when studying from home using online has many challenges. According to Small (2014), learning of language occurs in many forms and fashions. Self-study is one of the most common and significant means of learning a language. From a personal perspective, a learner can progress and enhance her language knowledge and skills from as little as an hour's self-study a week. We cannot disregard the fact that many learners can't study language via online resources (Krishan et al., 2020). The government, in this case is the Minister of Education and Culture, decided to close the school. Teachers and students learn from home.

The current study investigated the challenges in Online Learning During Covid-19 Pandemic and how the teacher overcome the obstacles they faced in online learning. Based on the background of the study above, the research questions were formulated as follows:

1. How do Vocational EFL teachers perceive the challenges of Online Learning during the covid-19 pandemic in Balikpapan?

2. How do Vocational EFL teachers overcome the challenges in Online Learning during the covid-19 pandemic?

\section{LITERATURE REVIEW}

\subsection{Online Learning}

Online is media with many forms in academic literature, including cyber, digital, virtual, e-media, network media, and new media (Nasrullah, 2014). According to Yusnilita (2020) stated information and technology developing rapidly support online learning. Technology and information support some of us in making it easier for teachers and students to carry out our daily activities, from messages, assignments, and online communication through message and assignments to improve several things online. Online learning often occurs via the internet, which is also called e-learning, different term to distance learning. According to SepulvedaEscobar \& Morrison (2020), learning in the classroom can use ICT as a source of learning material. In learning-based online, there are synchronous and asynchronous 


\section{Hermansyah and Aridah}

approaches. Fieldman (cite in Windiarti et al. (2019) said that synchronous learning is defined as real conditions and situations via the internet using devices such as direct messages, shared screens by connecting data in the form of video and audio, while asynchronous learning is defined as a process of learning that can delay the time. According to Bailin \& Battersby (2017), a pedagogical transformation is potentially from Forum-based online teaching. There are several potential forms in ICT for education, namely: functioning as an associate degree enabler or extended learning; making changes in the role of teachers in teaching and therefore the role of scholars in learning; offers open access to interactive materials and data over the network; eliminating space and space in the learning environment; supporting the organization and management of learning and education, and open opportunities for collaboration between academics and between students.

\subsection{Perception}

Perception is the experience of an event or object and the relationship obtained by continuing information and interpreting messages. It gives meaning to stimulusresponse in continuing information and predicting messages involving attention, expectation, motivation, and memory (Rahmat, 2000). Following it, Michotte (2017) expands perception as a phase of the total process of action that allows people to adapt their activities to the world we live in. Perception is thinking about what has been done, and that can be done with behavior. Teachers' perceptions form a prominent component to describe the environment of the learning process (Lee \& Tsai, 2005). Here, the teachers' perception can be described as the developed opinion after a certain experience needs adjustment. Therefore, in this research, the teachers' perception is focused on the challenges in Online Learning in Teaching English During Covid-19 Pandemic. Those factors are necessary to bring the teachers' perception of online learning to be more contextual with the needs of this research.

\subsection{The Covid-19 Pandemic}

COVID-19 is Coronavirus Disease 2019, a virus that attacks human respiration. Coronavirus is a kind of virus that causes diseases ranging from mild to severe symptoms. This type of virus is known to cause diseases that can cause severe symptoms such as Middle East Respiratory Syndrome (MERS) and Severe Acute Respiratory Syndrome (SARS) (Kemenkes, 2020). According to Kemendagri (2020), several actions must be taken to prevent this virus, namely carrying out hand hygiene by using a hand sanitizer, washing hands with soap if the hands look dirty, avoiding eye, nose, and mouth supervision. Applying cough etiquette or sneezing by covering the nose and mouth with the inner upper arm or tissue. Then, throwing the tissue in the trash, wearing a medical mask if you have respiratory symptoms, and doing hand hygiene after removing the mask, keeping a distance at least 1 meter from the person experiencing the disorder respiration (Kemdikbud, 2020). 
The impact of the COVID-19 caused the economy in Indonesia to decline, dropped the rupiah exchange rate, and the prices of goods rose, especially medical devices. It also has an impact on the education system in Indonesia. The result of the decision from education is that all learning activities both at school and college are carried out in their respective homes through the available applications. Mailizar, et al. (cite in Adnan \& Anwar (2020) said covid-19 has had a serious impact on students, instructors, and educational organizations around the world. Bozkurt \& Sharma (2020) stated that the failure of planning, communication, and coordination make many countries placing an additional burden on students, parents, and teachers. Regarding the prevention of covid-19, schools and colleges should be closed (Kemdikbud, 2020).

\section{RESEARCH METHODOLOGY}

This research employed the descriptive method with a qualitative approach. The study focused on obtaining data through Interviews and observation. Using this method, the researcher tried to reveal the challenges in online learning in teaching English during covid-19 pandemic based on teachers' perceptions. The researcher chose the subjects of this research who could provide depth-interview and detailed information based on their voluntary. They were three English teachers of SMK Nusantara Balikpapan and her students in an English teaching and learning process.

The main instrument of this research is the researcher himself. The researcher used interview instrument to interview the teachers. The interview contains semistructured questions. The teachers were interviewed based on the interview instrument and some questions appeared in the interview process. The data of this research was from a semi-structured interview of three English teachers about their perception of challenges in Online Learning in Teaching English During Covid-19 Pandemic. Three English Teachers of SMK Nusantara Balikpapan (called T1, T2, and T3) volunteered to participate in this research. The data were collected by doing an in-depth interview. The activity lasted about twenty minutes for each teacher and it was recorded using a special means designed especially for recording. The data were transcribed before they were analyzed.

The data were analyzed in the following procedure: transcribing the recorded data, classifying the data based on an interview to obtain the challenges in Online Learning in Teaching English During Covid-19 Pandemic are found in the research, reducing the data and taking only the data which showed significant contribution to the variables being studied, giving codes to each piece of an interview that is going to be discussed in the study, analyzing the data Thematically in terms of obtaining the challenges in online learning in teaching English during covid-19 pandemic investigated, and interpreting the data to answer the research questions.

Indonesian Journal of EFL and Linguistics, 6(1), 2021 


\section{Hermansyah and Aridah}

\section{FINDINGS}

This research used qualitative research study methods and research approaches using a descriptive qualitative used to obtain the data about the obstacles, the impact, and teacher recommendation of online learning in teaching English during covid-19 pandemic based on teachers' perception. According to Fraenkel et al. (2008) descriptive is to find out how people think or feel or to describe how they behave in a particular situation. Size samples are based on attainment of depth and richness of description, not on sample size. Semi-structured interviews were conducted. The respondents for this study were English teachers of SMK Nusantara Balikpapan and three students. In qualitative research, the purposive sampling technique is a method to achieve aims for specific research. There is no limit to the number of participants to make a purposive sample since provided the desired information can be obtained and generated (Bernard, 2013).

\subsection{The Interview Results}

This section delivers three key themes related to online learning in teaching English: obstacles, the impact encountered, and recommendations. It includes what English teachers use platforms and applications, how they overcome the obstacles of online learning in teaching English, and the impact of online learning, especially in teaching English subjects. All teachers give some advice and recommendations. For each theme, the most representative extracts from the respondents' responses are picked out. The researcher is labelled as ' $R$ ' whereas the teacher is labelled as ' $T 1$, T2, T3'.

\section{4..1.1. The use of Applications and platforms}

The teachers used several applications and platforms such as WhatsApp, Google Classroom, Zoom Meeting, Google Form, Youtube, and e-learning SMK Nusantara.

Table 1. Applications and platforms used by the teachers.

\begin{tabular}{|c|c|c|c|c|}
\hline No & $\begin{array}{c}\text { Application or } \\
\text { Platforms }\end{array}$ & $\mathrm{T} 1$ & $\mathrm{~T} 2$ & $\mathrm{~T} 3$ \\
\hline 1. & WhatsApp & $\begin{array}{l}\text { "I use WhatsApp at the } \\
\text { beginning, to } \\
\text { communicate with my } \\
\text { student and I made a } \\
\text { group for each class" }\end{array}$ & $\begin{array}{l}\text { "I only use } \\
\text { WhatsApp to share } \\
\text { my material" }\end{array}$ & $\begin{array}{l}\text { "I mostly use } \\
\text { WhatsApp in online } \\
\text { learning process, I } \\
\text { communicate with my } \\
\text { student in WhatsApp } \\
\text { group" }\end{array}$ \\
\hline 2. & $\begin{array}{l}\text { Google } \\
\text { Classroom }\end{array}$ & $\begin{array}{l}\text { "Google classroom for } \\
\text { delivering my material } \\
\text { and assignment" }\end{array}$ & - & $\begin{array}{l}\text { "I personally comport } \\
\text { using google classroom } \\
\text { than e-learning because } \\
\text { google classroom is not } \\
\text { heavy when I opened" }\end{array}$ \\
\hline 3. & Zoom Meeting & $\begin{array}{l}\text { "sometime I use zoom } \\
\text { meeting" }\end{array}$ & $\begin{array}{l}\text { "I use zoom meeting } \\
\text { to explain the } \\
\text { material and for }\end{array}$ & $\begin{array}{l}\text { "if possibly I use zoom } \\
\text { meeting to explain } \\
\text { detail about the }\end{array}$ \\
\hline
\end{tabular}




\begin{tabular}{|c|c|c|c|c|}
\hline & & & speaking material" & material" \\
\hline 4. & Google Form & $\begin{array}{l}\text { "I use Google Form to } \\
\text { make quiz and for } \\
\text { student's attendance" }\end{array}$ & $\begin{array}{l}\text { "for student's } \\
\text { attendance I use } \\
\text { google form" }\end{array}$ & - \\
\hline 5. & Youtube & $\begin{array}{l}\text { "I sometimes share link } \\
\text { from youtube" }\end{array}$ & $\begin{array}{l}\text { "I only familiar with } \\
\text { WhastApp and } \\
\text { Youtube" }\end{array}$ & $\begin{array}{l}\text { "I share video from } \\
\text { Youtube" }\end{array}$ \\
\hline 6. & Other & $\begin{array}{l}\text { "Actually, we have own } \\
\text { e-learning in this school" }\end{array}$ & $\begin{array}{l}\text { "We have own e- } \\
\text { learning in this } \\
\text { school" }\end{array}$ & $\begin{array}{l}\text { "This school has e- } \\
\text { learning and we use it } \\
\text { for final exam or share } \\
\text { the material" }\end{array}$ \\
\hline
\end{tabular}

Table 1 shows that the primary application teachers employ WhatsApp in the online learning process to communicate with their students and share materials. The teachers also employed Google Classroom to deliver teacher materials, and they felt Google Classroom is easy to access. The teacher employed Zoom Meeting to explain the material and for teaching of speaking. Google Form also was employed by the teacher for Quiz and taking students' attendance. The teacher also used Youtube to share English learning video with students. The another application is elearning to share material and for semester examination.

\subsubsection{The obstacles teacher faced in teaching English online}

From interviews, some themes emerged in analyze the data. The teachers' obstacles in teaching English online and how the teachers increase their knowledge to overcome the obstacles can be shown from the transcript of interviews. The researcher has asked some questions to the teacher. The questions were semi-structured. Some themes shown on the table below.

Table 2. The obstacles teacher faced in teaching English online

\begin{tabular}{|c|c|c|c|c|}
\hline No & The Obstacles & $\mathrm{T} 1$ & $\mathrm{~T} 2$ & T3 \\
\hline 1. & $\begin{array}{l}\text { Internet } \\
\text { Connection }\end{array}$ & $\begin{array}{l}\text { "internet connection, } \\
\text { sometimes our } \\
\text { internet networking } \\
\text { not stable, plus, } \\
\text { internet quota, } \\
\text { suddenly run out" }\end{array}$ & - & $\begin{array}{l}\text { "I think the most } \\
\text { obstacle that I found } \\
\text { when I was teaching } \\
\text { is accessibility" }\end{array}$ \\
\hline 2. & Quota Internet & $\begin{array}{l}\text { "plus quota internet, } \\
\text { suddenly my internet } \\
\text { quota run out, so I } \\
\text { must go to refill my } \\
\text { quota" }\end{array}$ & - & $\begin{array}{l}\text { "No, ... eehm ... } \\
\text { Quota Internet } \\
\text { maybe..." }\end{array}$ \\
\hline 3. & $\begin{array}{l}\text { Teachers } \\
\text { Knowledge }\end{array}$ & $\begin{array}{l}\text { "When I teaching } \\
\text { English is more } \\
\text { difficult to explain, } \\
\text { specially grammar } \\
\text { material and writing } \\
\text { skill" }\end{array}$ & $\begin{array}{l}\text { "For me, the problem is } \\
\text { because I don't } \\
\text { understand how to } \\
\text { operate existing } \\
\text { technology or } \\
\text { application software }\end{array}$ & - \\
\hline
\end{tabular}




\section{Hermansyah and Aridah}

$\begin{array}{llll}\text { 4. Time Schedule } & \text { "When I teach the } & \text { "as a teacher, we are } & \text { "I just have an hour } \\ \text { grammar, I need time } & \text { required to provide } & \text { every week to } \\ \text { to explain in order to } & \text { material that the } & \text { conduct my learning } \\ \text { the student } & \text { students can } & \text { process and the rest } \\ & \text { understand, moreover } & \text { understand but because } & \text { through online } \\ \text { I have only one } & \text { time and everything is } & \text { answer and question } \\ \text { meeting every week } & \text { limited, we cannot give } & \text { and assignment. } \\ \text { and that is very } & \text { the material a hundred } & \\ \text { limited time for me". } & \text { percent". }\end{array}$

Table 2 shows that the teachers' obstacles in online English learning have four themes of obstacles, the first is an internet connection, this is the common obstacles the teachers faced in online learning, and that findings supported by Windiarti et al., (2019) stated that one of the problems in the device is the internet connection because every place has a different strength of the internet connection. The second is the internet quota. The teacher needed internet quota in their cellular phone to communicate or share materials to students, especially to open online application or platform. The third is teachers' knowledge where information and technology skill is required to the learning process. The last theme is the time management schedule. During online learning, time in the learning schedule is reduced to accommodate all subjects before the pandemic teacher had 2 hours of lessons and 2 times a week become only one meeting in a week.

\subsubsection{The Impact of Online Learning in Teaching English}

Online English teaching has some impacts on English teaching; negative impact and positive impact, and some impacts shown on the table below:

Table 3. The impacts of online learning in teaching English

\begin{tabular}{|c|c|c|c|c|}
\hline No & The Impact & $\mathrm{T} 1$ & $\mathrm{~T} 2$ & $\mathrm{~T} 3$ \\
\hline 1. & Motivation & - & $\begin{array}{l}\text { "I am less motivated to } \\
\text { learn more about IT." }\end{array}$ & $\begin{array}{l}\text { "the students" } \\
\text { motivation is one of my } \\
\text { challenge" }\end{array}$ \\
\hline 2. & Plagiarism & $\begin{array}{l}\text { "in online, students } \\
\text { can cheat or view } \\
\text { answers on the } \\
\text { internet because } \\
\text { there is no } \\
\text { supervision" }\end{array}$ & - & $\begin{array}{l}\text { "I can not supervise the } \\
\text { student in assignment, } \\
\text { they were easy for } \\
\text { cheat or find the } \\
\text { answers by browsing } \\
\text { the internet" }\end{array}$ \\
\hline 4. & IT Literate & - & $\begin{array}{l}\text { "But one think that we } \\
\text { can get is, I personally } \\
\text { get a lot of knowledge } \\
\text { about using existing } \\
\text { applications and the } \\
\text { technology where before } \\
\text { the pandemic I had never } \\
\text { used it" }\end{array}$ & $\begin{array}{l}\text { "I think maybe the } \\
\text { positive thing we can } \\
\text { learn from online } \\
\text { learning, I know more } \\
\text { about online } \\
\text { applications and how to } \\
\text { use them, which I } \\
\text { rarely used before" }\end{array}$ \\
\hline
\end{tabular}


Table 3 shows the impacts of online English teaching both negative and positive impact. Many researches on online learning studies have found that the negative impact of online learning on them was internet access. Sujarwo et al. (2020) stated that students have to pay higher internet access than before the covid-19 pandemic. The internet access were slower access in remote areas than students in the city. So, the students had difficulty interacting. On the other hand, it was very rare to find the study of positive impact. The present study found there was positive impact on teachers' perception. The teachers are more adaptable to using technology during study from home due to covid19 pandemic. Teachers have to use technology to conduct learning process from home and the teachers are accustomed to using it.

\subsubsection{Recommendations to Overcome the Obstacles}

\begin{tabular}{|c|c|c|c|c|}
\hline No & Recommendations & $\mathrm{T} 1$ & $\mathrm{~T} 2$ & $\mathrm{~T} 3$ \\
\hline 1. & Teacher Ability & $\begin{array}{l}\text { "I also use video } \\
\text { learning in } \\
\text { youtube, I share } \\
\text { the link and ask } \\
\text { the student to } \\
\text { study about that" }\end{array}$ & $\begin{array}{l}\text { "we must continue to } \\
\text { learn about existing } \\
\text { technology, especially } \\
\text { myself, because this } \\
\text { learning process can } \\
\text { run as much as } \\
\text { possible, because only } \\
\text { with technology can } \\
\text { we carry out the } \\
\text { learning process } \\
\text { during this } \\
\text { pandemic." }\end{array}$ & $\begin{array}{l}\text { "To increase student } \\
\text { motivation, I usually } \\
\text { use video from Youtube } \\
\text { because most of student } \\
\text { are interesting with } \\
\text { contents in Youtube" }\end{array}$ \\
\hline 2. & Teachers'Attitude & - & $\begin{array}{l}\text { "I think, as a teacher } \\
\text { we must be patient in } \\
\text { dealing with the } \\
\text { obstacle that we } \\
\text { found, and specially } \\
\text { to our student" }\end{array}$ & $\begin{array}{l}\text { "I think patient is the } \\
\text { main key in the online } \\
\text { learning process, } \\
\text { besides that we have to } \\
\text { keep thinking positively } \\
\text { about this situation so } \\
\text { that our health can be } \\
\text { maintained" }\end{array}$ \\
\hline
\end{tabular}

Table 4 shows two themes of recommendation to overcome the teachers' obstacle. The Online learning method is still new for the teachers and students as well; in employ them, the teachers need the training to learning process running well. They still found some difficulties, and they still need to learn more about the application and platforms they use during online learning in teaching English subjects. They should be aware of the technology. It will affect to achieve the learning purpose. Then, the teachers should have a good attitude toward the students' response in online English teaching. 


\section{Hermansyah and Aridah}

\section{DISCUSSION}

The present research provides descriptive information about the challenges of online learning in teaching English subject during covid-19 pandemic based on the teachers' perception in SMK Nusantara Balikpapan. Regarding the findings mention above, various platforms and applications ranging from learning management systems to an additional resource are employed to carry out online learning in teaching English subjects. Ilmiani (2020) stated that choices of teaching media, WhatsApp Group, Zoom Cloud Meeting, and Google Classroom, is because students have a tendency to choose these applications based on some reasons. The teachers have found a number of platforms to create teaching materials and help my students (Sepulveda-Escobar \& Morrison, 2020).

However, many problems emerged from the teachers and the students who were involved in the learning process. Sepulveda-Escobar \& Morrison (2020) found that this uncommon experience of EFL teachers had to go through, challenges emerged that seem to affect teacher education. Online learning does not run well since it lacked the ability to use the application or platform and limited time. The obstacles of e-learning, that is, still a new thing for them (Adnan \& Anwar, 2020). The challenging issue, the teachers should use the online learning platform during the pandemic covid-19 (Irfan et al., 2020). In this research, the researcher found the teachers' obstacles and the impact of the online learning process in teaching English and the recommendations to overcome the obstacles. The findings will be discussed below.

5.1. The Teachers' Obstacles of online teaching English online.

Online learning becomes something new at school. The teachers should be able to employ the learning into the online classroom. The use of ICT as media in teaching is a very important element in the online learning process. The teachers faced some obstacles when they employ it. Some obstacles faced by the teacher describe below:

\section{Internet Connection}

The common obstacle of the online learning process is an unstable connection of the internet. The teachers described challenges in connecting with students whose limited device and internet access (Code et al., 2020). In line with it, Sujarwo et al. (2020) found that an unstable network makes it difficult for the teacher to deliver the material when the connection is bad. The teacher can teach English from home using online applications and platforms. Online learning does not require investments in infrastructure on the user's side if a computer and internet access is available. Every place has a different strength of internet connection. It can be from everywhere. On the other hand, it can be from their connection to their device. It related to the findings that two teachers said that Internet connection was not stable. If there are some problems with an internet connection, the teachers were busy handling their devices. Internet connection has an essential role, and it will affect learning process. 
If the internet connection can run effectively, the learning process had not a problem with the internet connection. The findings supported by Windiarti et al. (2019) stated that one of the problems in the device is the internet connection because every place has different strengths of the internet connection.

\section{Internet Quota}

Besides internet connection, the teachers also felt that internet quota also matters in online learning. It needs money to buy the quota, especially teachers who used a cellular phone as their primary device to communicate and share material to students using online application platforms. Although the school provides Wireless Fidelity (Wifi) at school, sometimes when the teachers teach at home, they have not Wifi and rely on quota. If the quota run out in the middle of the learning process, it will be interrupted and even stopped until the teacher's internet quota is refilled, in line with what the teacher said in their interview:

"And, quota internet, suddenly my internet quota run out, so I must go to refill my quota"

Even though the government gave an internet quota for teachers, it was still not enough to cover the quota needed by teachers in online learning. Moreover, many teachers did not get the quota because there were several requirements from the government to get the internet quota.

\section{Teachers' Knowledge}

The teacher should have good knowledge and a good understanding of ICT. It was because of teachers' knowledge of the materials and applying them into the online class. Teachers' perceptions form a prominent component to describe the environment of the learning process (Lee \& Tsai, 2005). It means that the assumption of the teachers toward online learning is fundamental. Moreover, to succeed in the educational institutions must accept, implement, and adopt technological advancements, including the application and platform. The teachers should know how to apply online learning applications and platforms. The teachers still have a problem with it. Based on the findings, the teacher thought online applications or platforms are still new, and the teacher still has low awareness of the technology.

"For me, the problem is because I don't understand how to operate existing technology or application software."

Information and technology in online learning is a must and essential to learn. The teachers should be aware of the technology because if the teachers do not know about it, they will be confused with online applications and platforms. There was no way to conduct learning processes in a pandemic situation. So, the teachers should study technology to make it accessible in the teaching process. 


\section{Hermansyah and Aridah}

\section{Time Schedule}

Time Schedule is one of the teachers' obstacles that should be overcome. The school provided limited time for teachers' schedule, that is, the schedule must divide to other teachers. Each teacher got the same schedule and is evenly distributed due to time constraints. The teacher only got a learning schedule once a week for approximately 2 hours, which the local government has regulated. In this case, Dinas Pendidikan dan Kebudayaan kota Balikpapan, that every day is only allowed to learn from 8 am to 12 at noon, this is different from the learning time before the Covid-19 pandemic where previously the English learning schedule was 3 to 4 learning hours in one week. The teachers should be able to divide time based on students' needs. The new method of online learning becomes more suitable than face-to-face in the classroom. The communication was very limited, and the interactions between teacher and student were limited. When internet connection unstable made the timeless, it means that online learning is not effective. Based on the finding, the teachers said that learning English need more time in meeting:

"When I teach the grammar, I need time to explain to the student understand, moreover I have only one meeting every week, and that is very limited time for me" (T1).

"as a teacher, we are required to provide material that the students can understand but because time and everything is limited, we cannot give the material a hundred percent" (T2)

The teacher also was able to divide the time both of operating online applications and studying English. So, the teachers need to manage the time to make the teacher teaching English effectively. Not only learn how to apply online platform and application but also learn to practice English. The learning process can be done online learning or face to face. It depends on the teachers in managing the time.

\subsection{The impact of online learning in teaching English}

Online English teaching has some impact on the English teacher; besides the negative impact caused by online learning, there is also the positive impact that arose from online learning in teaching English subject. The impact describes below:

\section{Motivation}

Motivational problems can be called as non-technical obstacles that arose as a result of online learning. Teaching English online by technology using applications or platforms can decrease the teacher and students' motivation. The biggest challenge for online language teaching is not technology or its subject matter but in motivating learners to participate in the lesson (Krish, 2008). The students operated the application, and they faced some problems. When they tried to solve the problems, they could not face them. They felt that it is not essential. So, students' motivation can be influenced by where they study and the tools that they used. The teachers are 
just facilitators to guide the students in using the tools. The ability of the students also can influence operating the tools. The students would feel interested in the beginning, but their motivation will decrease if they have some problems.

\section{Plagiarism}

The second impact arose when online learning in teaching English subjects could easily cheat or search for answers by browsing the internet without being noticed by the teacher because they cannot be supervised. On the internet, everything is easy and possible. When the teacher gave an assignment or task to students, they easily copy-paste and find the answer through the internet. The plagiarism issue is the most difficult thing to find its solution. The finding showed the teacher difficulty in supervised the student.

"In online learning, students can cheat or view answers on the internet because there is no supervision" (T1).

"I cannot supervise the student in an assignment, they were easy for cheat or found the answers by browsing the internet" (T3)

\section{IT Literate}

Besides negative impact, the findings also found positive impact: the teachers become IT literate and can operate various existing online applications or platforms. Teachers become more creative in learning because they wanted or not, like it or not, they had to use the application so that learning process can continue well. The finding shows a positive impact based on teacher experience:

"But one thing that we can get is, I personally get a lot of knowledge about using existing applications and the technology where before the pandemic I had never used it" (T2).

"I think maybe the positive thing we can learn from online learning; I know more about online applications and how to use them, which I rarely used before" (T3).

\subsection{Recommendation to overcome the obstacles}

Many obstacles that teachers faced in online learning during the covid-19 pandemic. In teaching English, the teacher needs more time to explain their material to the student to understand English material, and the teachers did not want other teachers to have the same problems. So, they gave some suggestions to other teachers at others schools. The teacher suggests that in the online learning process, the teacher should endure some of the problems found during the learning process from home, and if the teacher is impatient in facing the obstacles the learning process will not go well. In addition, besides teacher patient, willingness and enthusiasm to learn about various existing applications or platforms very important as well, because in the process of online learning, a teacher has no choice in teaching other than using communication and information technology. Regarding unstable internet networks 
were very often, it is the responsibility of the parties concerned and the government to immediately find the best solution so that the learning process from home is not interrupted and runs smoothly so that education in our country is not left behind.

\section{CONCLUSION}

The present research revealed that online language learning in teaching English subjects was new and never imagined before. The teachers have carried out online learning from home synchronously or asynchronously due to the covid-19 pandemic. English teachers faced some obstacles in implementing online learning. Various platforms and applications ranging from learning management systems to the additional resources are employed to carry out online learning. However, many problems emerged from the teachers or students. As a result, the online learning process in teaching English did not run well since it lacks preparation and planning.

\section{REFERENCES}

Adnan, M., \& Anwar, K. (2020). Online Learning amid the COVID-19 Pandemic: Students' Perspectives. Online Submission, 2(1), 45-51.

Aliyyah, R. R., Rachmadtullah, R., Samsudin, A., Syaodih, E., Nurtanto, M., \& Tambunan, A. R. S. (2020). The perceptions of primary school teachers of online learning during the Covid-19 pandemic period: A case study in Indonesia. Journal of Ethnic and Cultural Studies, 7(2), 90-109.

Bailin, S., \& Battersby, M. (2017). What Should I Believe?

Bernard, H. R., \& Bernard, H. R. (2013). Social research methods: Qualitative and quantitative approaches. Sage.

Bozkurt, A., \& Sharma, R. C. (2020). Emergency remote teaching in a time of global crisis due to CoronaVirus pandemic. Asian Journal of Distance Education, 15(1), i-vi.

Code, J., Ralph, R., \& Forde, K. (2020). Pandemic designs for the future: perspectives of technology education teachers during COVID-19. Information and Learning Sciences.

Ilmiani, A. M. (2020). The Use of Teaching Media in Arabic Language Teaching During Covid-19 Pandemic.

Irfan, M., Kusumaningrum, B., Yulia, Y., \& Widodo, S. A. (2020). Challenges during the pandemic: use of e-learning in mathematics learning in higher education. Infinity Journal, 9(2), 147-158.

Jack R. Fraenkel; Norman E. Wallen; Helen H. Hyun. (2008). How to Design and Evaluate Research in Education (7th ed.). McGraw-Hill.

Kemdikbud, R. I. (2020). Edaran Tentang Pencegahan Wabah COVID-19 di Lingkungan Satuan Pendidikan Seluruh Indonesia. Indonesia: Kemdikbud RI.

Kemendagri. (2020). Pedoman Umum Menghadapi Pandemi COVID-19 Bagi Pemerintah Daerah.

Kemenkes (2020). Pedoman Pencegahandan Pengendalian Coronavirus Disease (COVID-19). 
Krish, P. (2008). Language Learning in the Virtual World: Instructors' Voices. International Journal of Pedagogies and Learning, 4(4), 113-129. https://doi.org/10.5172/ijpl.4.4.113

Krishan, I. A., Ching, H. S., Ramalingam, S., Maruthai, E., Kandasamy, P., De Mello, G., Munian, S., \& Ling, W. W. (2020). Challenges of Learning English in 21st Century: Online vs. Traditional During Covid-19. Malaysian Journal of Social Sciences and Humanities (MJSSH), 5(9), 1-15.

Lauder, A. (2008). the Status and Function of English in Indonesia: a Review of Key Factors. Makara Human Behavior Studies in Asia, 12(1), 9. https://doi.org/10.7454/mssh.v12i1.128

Lee, T. S., \& Tsai, H. J. (2005). The effects of business operation mode on market orientation, learning orientation and innovativeness. Industrial Management and Data Systems, 105(3), 325-348. https://doi.org/10.1108/02635570510590147

Michotte, A. (2017). The perception of causality (Vol. 21). Routledge.

Miles, M. B., Huberman, A. M., \& Saldana, J. (2014). Fundamentals of qualitative data analysis. Qualitative Data Analysis: A Methods Sourcebook, 69-104.

Nasrullah, R. (2014). Teori dan Riset Media Siber (Cybermedia): Edisi Pertama. Jakarta: Kencana Media Group.

Navarro, O., Sanchez-Verdejo, F. J., Anguita, J. M., \& Gonzalez, A. L. (2020). Motivation of university students towards the use of information and communication technologies and their relation to learning styles. International Journal of Emerging Technologies in Learning, 15(15), 202-218. https://doi.org/10.3991/ijet.v15i15.14347

Rahmat, Jalaluddin. (2000). Psikologi komunikasi. Kanisius.

Sepulveda-Escobar, P., \& Morrison, A. (2020). Online teaching placement during the COVID-19 pandemic in Chile: challenges and opportunities. European Journal of Teacher Education, 43(4), 587-607. https://doi.org/10.1080/02619768.2020.1820981

Small, M. (2014). Theoretical implementations of various mobile applications used in English language learning. Teaching English with Technology, 14(1), 35-46.

Sujarwo, S., Sukmawati, S., Akhiruddin, A., Ridwan, R., \& Siradjuddin, S. S. S. (2020). An Analysis of University Students' Perspective on Online Learning in the Midst of Covid-19 Pandemic. Jurnal Pendidikan Dan Pengajaran, 53(2), 125-137.

Windiarti, S., Fadilah, N., Dhermawati, E., \& Pratolo, B. W. (2019). Teachers' Perception toward the Obstacles of E-Learning Classes. Ethical Lingua: Journal of Language Teaching and Literature, 6(2), 117-128. https://doi.org/10.30605/25409190.v6.117-128

Yusnilita, N. (2020). The impact of online learning: Student's views. ETERNAL (English Teaching Journal), 11(1). 